\title{
FATHOM
}

FATHOM a French e-journal of Thomas Hardy studies

$1 \mid 2013$

The Letter

\section{A note on the text}

\section{(2) OpenEdition \\ 1 Journals}

\section{Electronic version}

URL: http://journals.openedition.org/fathom/302

DOI: $10.4000 /$ fathom.302

ISSN: 2270-6798

\section{Publisher}

Association française sur les études sur Thomas Hardy

\section{Electronic reference}

"A note on the text », FATHOM [Online], 1 | 2013, Online since 15 July 2013, connection on 22 September 2020. URL : http://journals.openedition.org/fathom/302 ; DOI : https://doi.org/10.4000/ fathom.302

This text was automatically generated on 22 September 2020. 


\section{A note on the text}

1 The following text is the introduction to the thesis defended in 1983 at the University of Montpellier by our colleague Annie Escuret: “L'œuvre romanesque de Thomas Hardy (1840-1928): lecture". The thesis has since been a model and a source of inspiration for Thomas Hardy researchers in France. Had it been written in English, it would have enjoyed international fame, but unfortunately it was written in French-it was customary for French theses in those days to be monuments of over 1000 pages, written in French, two facts which tended to discourage translation and publication. Feeling that Annie Escuret's thesis had not been offered the circulation it deserved, we have decided to include its introduction in the first volume of the e-journal FATHOM, as a homage to Annie Escuret, now retired but an active member of our French Association for Thomas Hardy studies. That introduction is still untranslated, but by granting free access to it in an international e-journal, we hope to appeal to Hardy scholars with a good knowledge of the French language. Those researchers will then perhaps be prompted to make further inquiries into the different chapters of the thesis, which is available in most University libraries in France.

2 The introduction focuses on the gaze in Hardy's novels, studied jointly with the issue of desire. Hence the subtitle, whose main points could be roughly translated as "a visual Eros" and a "Way-sex named desire". Hardy's male characters may be divided into three categories: those who are bedazzled and fall prey to fascination; those who are blind; and those who are voyeurs. Only the voyeurs, like Gabriel Oak, manage to survive in a universe where the forces of dissolution are rampant. That "visual Eros", which is manifest in both microcosm and macrocosm, in individual destinies and cosmic evolution, is the form assumed by the passionate quest for indivisible Oneness. But the reader venturing through the pages of Annie Escuret's introduction will find a lot more than that: he will be gratified with innumerable gems of text analysis, that will make his effort at reading French worth while. 